\title{
Blue Orchard Bee, Osmia lignaria Say (Insecta: Hymenoptera: Megachilidae) ${ }^{1}$
}

\author{
Alden Estep, Catherine Zettel-Nalen, and James Ellis ${ }^{2}$
}

\section{Introduction}

The blue orchard bee, Osmia lignaria Say (Fig. 1), is a solitary mason bee native to the west coast of the United States and Canada. It is of great interest for use as a native pollinator of fruit trees and blueberries, and is easily

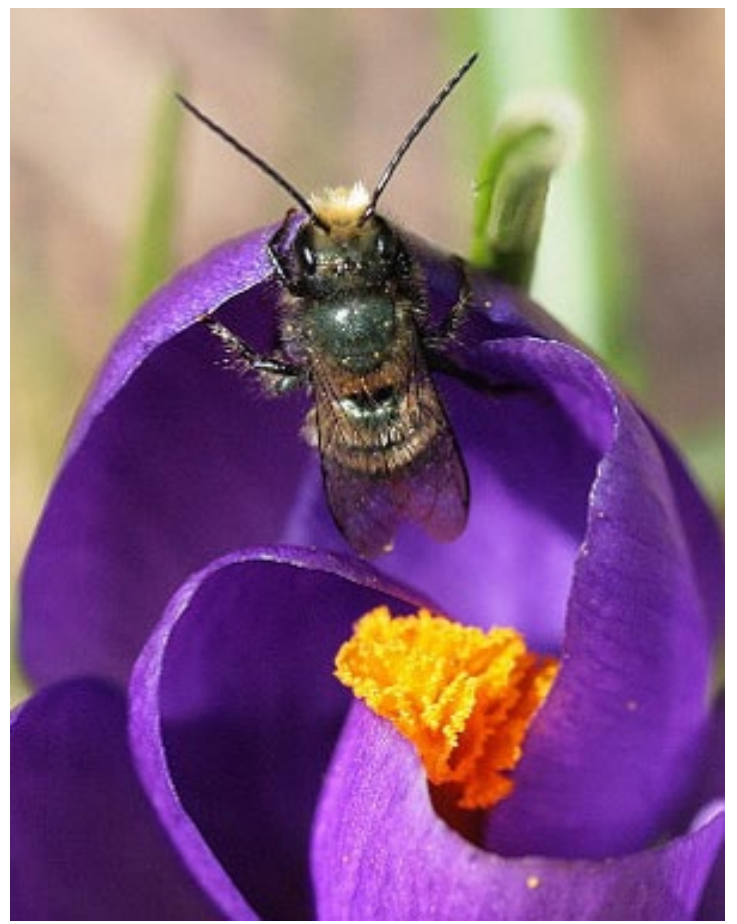

Figure 1. Male Osmia lignaria visiting a crocus flower in early spring in Ontario, Canada.

Credits: Seabrooke Leckie. managed due to its favorable biological characteristics. Blue orchard bees can be purchased online for pollination, and they are shipped as pupae ready to emerge in the spring.

\section{Distribution}

The blue orchard bee is native to the Pacific Northwest, but due to shipment for pollination, populations have established throughout much of the U.S. as far south as Georgia. Large overwintering losses due to warm winter temperatures prevent its establishment in Florida and along the Gulf coast.

\section{Description and Life History}

\section{Egg}

The egg is similar in size and color to a honey bee egg. It is cylindrical, whitish, and approximately $1.4 \mathrm{~mm}$ long. An egg is laid on a pollen ball, which is sealed up within a cell (Fig. 2).

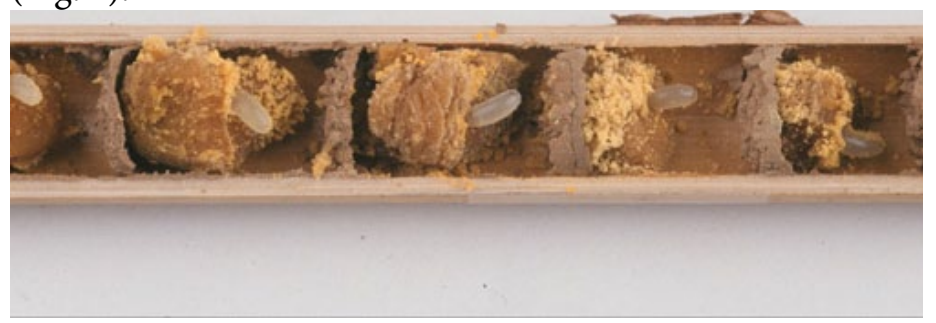

Figure 2. A piece of a bisected tube to show the pollen ball, Osmia lignaria egg, and the mud plug separating each cell.

Credits: USDA-ARS

1. This document is EENY-549, one of a series of the Entomology and Nematology Department, Florida Cooperative Extension Service, Institute of Food and Agricultural Sciences, University of Florida. Original publication date March 2013. Visit the EDIS website at http://edis.ifas.ufl.edu.

2. Alden Estep, student; Catherine Zettel-Nalen, Extension assistant; and James Ellis, assistant professor; Entomology and Nematology Department, Cooperative Extension Service, Institute of Food and Agricultural Sciences, University of Florida, Gainesville 32611. 


\section{Larva}

The developing larva is white and maggot-like in shape . It will develop through five instars, completing development 10 to 14 days after hatching. It feeds on the ball of collected pollen as it grows within the brood chamber.

\section{Pupa}

Once development of the fifth instar is complete, a cocoon is spun within the sealed brood chamber, where metamorphosis occurs. The pharate adult can remain in the cocoon until adult emergence the following spring.

\section{Adult}

The female measures approximately $14 \mathrm{~mm}$ in length. Her iridescent bluish-grey color may appear black, and her body is covered by small hairs, which collect pollen while she is visiting flowers (Fig. 3). When in flight, the blue orchard

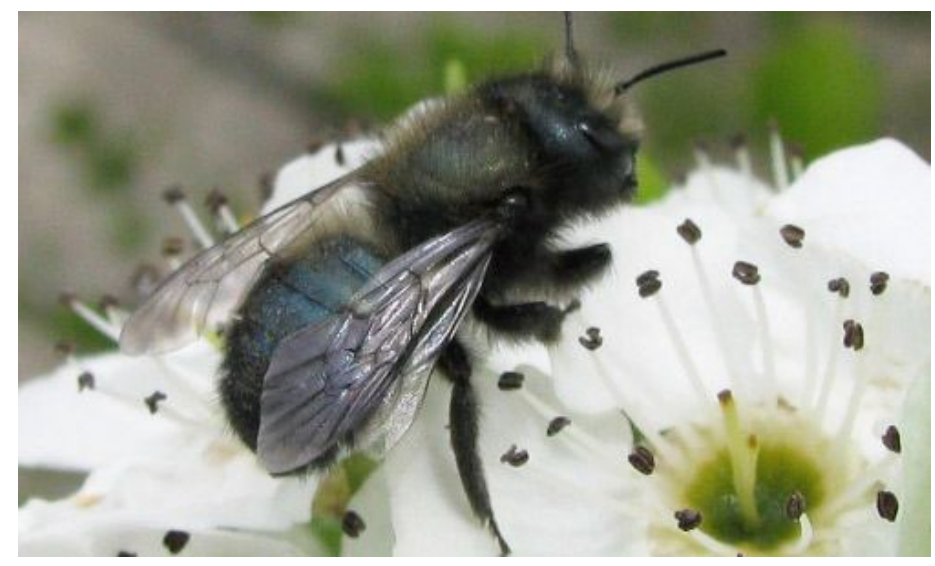

Figure 3. Female blue orchard bee visiting a flower in Utah. Females can be distinguished from males by their short antennae and absence of a pale facial tuft . Credits: Algidus

bee sometimes is mistaken for a black fly. As with other megachilids, the female packs pollen onto the underside of her abdomen to use in brood production. A female Osmia lignaria is distinguished from other Osmia species by a deep median emargination on her clypeus.

The male, approximately $11 \mathrm{~mm}$ long, is slightly smaller than the female. He can easily be distinguished from a female by his long antennae (and 13 segments rather than 12) and a light-colored hair tuft on the head (Fig. 4). Coloring of other body parts is similar to that of a female, though the dorsal surface of the male's body is not thickly covered with hairs. Several characters, which include long median antennal segments, must be used to separate male Osmia lignaria from other Osmia species.

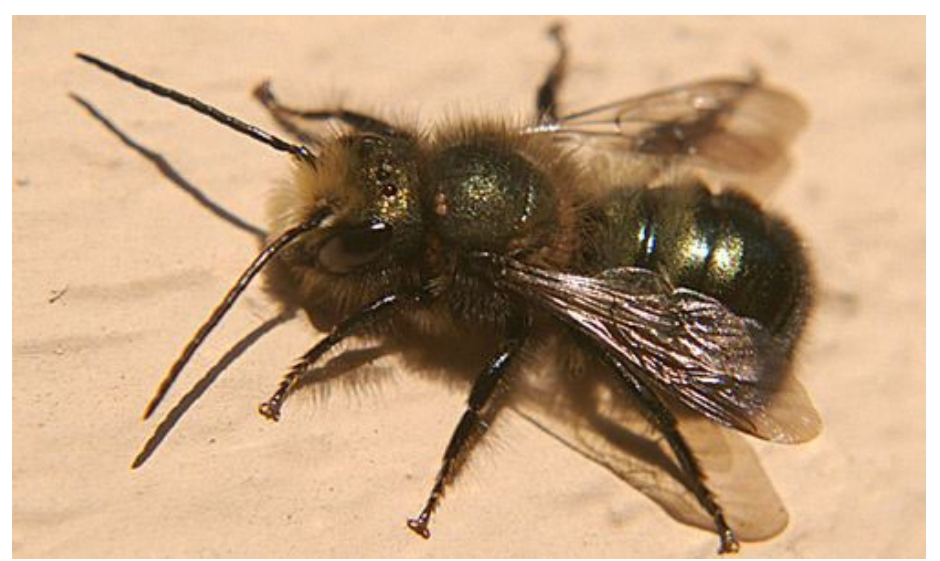

Figure 4. Male blue orchard bee resting. Males can be distinguished from females by their long antennae and pale facial hair tuft. Credits: Kevin Hall. BugGuide.net.

\section{Biology}

Blue orchard bees are active in the early spring and summer. During this time, they provision their brood nests with pollen. Nests are constructed in existing holes $(\sim 6$ $\mathrm{mm}$ in diameter), often in wood but sometimes in other locations such as hoses, bamboo, or abandoned pipes. They will occupy the holes left by other boring insects, or they will occupy paper tubes or paper straws used the previous year. Females generally create seven to eleven cells per nest.

Only one egg is laid per cell, and females can lay two to three eggs per day. Once a proper nesting site is located, the bee will collect mud to line the rear of what will become the first brood chamber. This will be followed by 12 to 25 pollen-collecting flights to provide a food ball for the soon to be deposited egg. Pollen from each flight is combined and packed into the rear portion of the brood cell, into which one egg is placed. The female seals this brood chamber with additional mud while leaving sufficient space for the young to develop. This seal provides the rear of the next brood chamber, and the process continues until the tube is filled (Fig. 2).

The first (farthest from the entrance) cells of brood usually house females and the last few usually males, thereby ensuring that males, which have a shorter development time than females, can exit first during spring emergence. The mud is a series of separate plugs rather than the continuous lining that is produced by many mason bees. This feature has allowed researchers to examine nests built in glass tubes and observe the larval growth process. Nests are usually provisioned and sealed by early summer. Larval growth continues unassisted throughout the summer, and pupation occurs in August and September. A cocoon 
is spun by the larva within its brood chamber in which metamorphosis occurs. The pharate adult remains in diapause in the cocoon through the winter and emerges in the spring.

Though solitary, blue orchard bees are gregarious, meaning several females will create nests near one another, making these bees suited for domestication. In the early spring, the juveniles from the previous season begin to emerge as adults by chewing through the mud plugs. Males often hover around the nest entrances and wait for the females to emerge for immediate mating.

\section{Pollination}

Females are excellent pollinators of apple, pear, and cherry trees in the Northwestern U.S. They are also efficient pollinators of fruiting bushes, such as blueberries, and have been shown to be successful at pollinating almonds. Due to their productive pollination habits, they have been imported into many areas of the country that are lacking sufficient numbers of native pollinators.

A nest block can be placed in an orchard and filled with purchased tubes full of overwintering adults. They emerge at the appropriate time to pollinate the orchard and, if appropriate nesting sites are available, will remain in the orchard through the following generation. United States Department of Agriculture recommendations suggest approximately 50 full nest tubes, which provide about 250-300 female bees per acre. Some crops, such as blueberries, will require more tubes per acre to provide adequate pollination.

\section{Management}

Nesting blocks can be made from 4 by 4 inch untreated lumber with several 6-mm (diameter) holes drilled 8 to 15 $\mathrm{cm}$ deep. Holes should be separated by approximately 12 to $18 \mathrm{~mm}$ (Fig. 5). It is recommended that parchment paper or other types of liners are used to line the holes. This increases sanitation as the paper lining can be removed each season to prevent the buildup of fungi and bacteria.

Alternatively, nesting blocks can be purchased pre-made with paper tubes that are already filled with overwintering pupae. A number of commercial suppliers provide stocks of tubes with or without pupae included. These types of nests can also be made at home using PVC pipe filled with paper straws, bamboo, or tubing (Fig. 6).

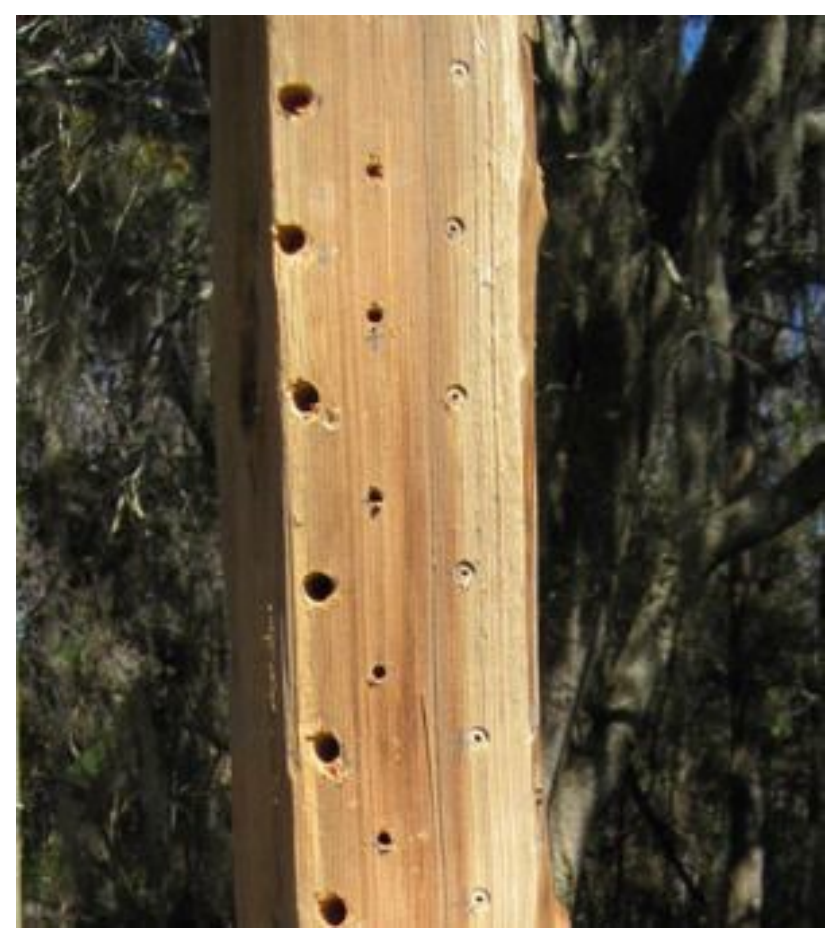

Figure 5. Lumber ( 4 by 4 inch) nesting block with holes drilled for native pollinator nesting sites. These holes have different sizes to attract a variety of native mason bee species.

Credits: Jason Graham

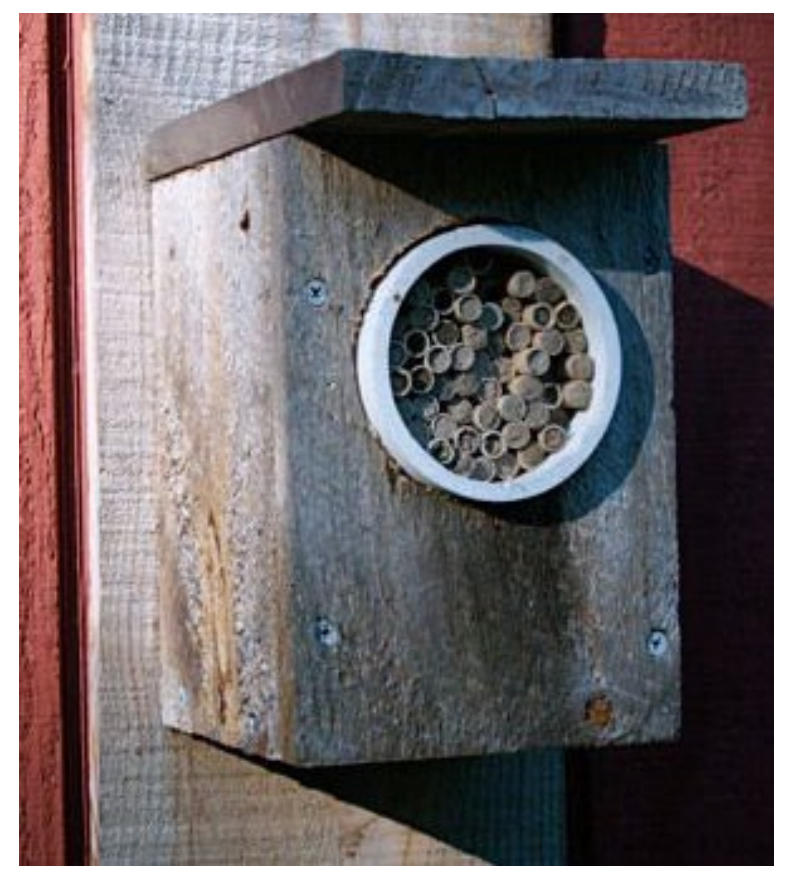

Figure 6. Purchased paper tubes are held in a PVC pipe inserted into a homemade nesting box.

Credits: M.J. Zettel 
After emergence, the emptied tubes can be removed, and new tubes can be inserted to provide nesting sites for the following generation. Reusing tubes is not recommended because soiled tubes often contain harmful entomopathogenic bacteria and fungi. Additional nesting blocks can be provided to expand the colony. Once tubes are filled and plugged (Fig. 7), they can be moved to other locations, or entire nesting blocks can be relocated.

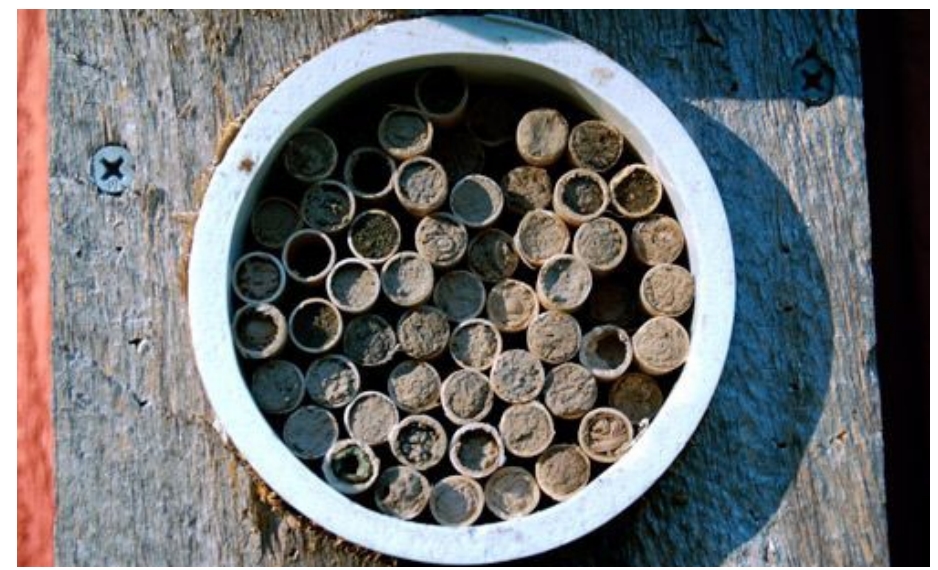

Figure 7. Paper tubes plugged with mud, indicating the bees have finished laying eggs in these tubes.

Blue orchard bees are not immune to pests and predators. Certain species of flies and wasps will chew through the plugs and consume the growing larvae as well as their food source. Parasitic Hymenoptera can be a problem in some locations, although infrequently. To combat predators, females often intentionally leave the first cell empty. Research on pathogens of blue orchard bees is lacking, but usually predators will take down colonies before disease. While it is fun to breed your own colony of bees, it may be necessary to supplement your nesting boxes with purchased bees annually.

\section{Selected References}

Bosch J, Kemp WP. 2001. How to manage the blue orchard bee. Sustainable Agricultural Network, Beltsville Maryland. $98 \mathrm{pp}$.

Bosch J, Kemp WP, Peterson SS. 2000. Management of Osmia lignaria (Hymenoptera: Megachilidae) populations for almond pollination: methods to advance bee emergence.

Bosch J, Kemp WP, Trostle GE. 2006. Bee population returns and cherry yields in an orchard pollinated with Osmia lignaria (Hymenoptera: Megachilidae). Journal of Economic Entomology 99: 408-413.

Stubbs CS, Drummond FA, Yarborough DE (2000) Field conservation management of native leafcutting and mason Osmia bees. University of Maine's Cooperative Extension: Maine's Native Wild Blueberries. (11 February 2013).

USDA (2010) Nesting block preparation. (11 February 2013). 